\title{
Histological Procedure
}

National Cancer Institute

\section{Source}

National Cancer Institute. Histological Procedure. NCI Thesaurus. Code C16680.

Technique or procedure used for the study of the microanatomy of tissues and their cellular structure; usually involves microscopic examination of tissue slices. 